\title{
Story Telling using Madihin: Learning Methods for Early Childhood Listening Skills
}

\author{
Eva Eriani $^{1}$, Dimyati ${ }^{2}$ \\ Pendidikan Anak Usia Dini, Universitas Negeri Yogyakarta
}

\begin{abstract}
In this research, the storytelling is combined with madihin, with the aim and enhancing listening skills as well as introducing a traditional state of art. The study involved 19 children for ages 5-6 years in RA Al-Amin, Tembilahan-Riau, The study design used one group pretest posttest design. The data which were collected using observations and interviews were analyzed by using quantitative descriptive techniques. The results showed that there was a significant effect in telling story using madihin on the listening skills of children aged 5-6 years which were shown in the post test results are indicates in higher rate than the results in the pre test. This can be seen when the child can sit neatly, enthusiastically, listen and pay attention to the story from beginning to end, can mention various characters and their characteristics, and can retell with their own languages. Madihin can attract children's interest and attention, so this art needs to be collaborated with other learning methods in order to develop aspects of child development such as cognitive, artistic, motoric, and social emotional.
\end{abstract}

Keywords: storytelling; madihin; listening skills

\begin{abstract}
Dalam penelitian ini bercerita dikombinasikan dengan kesenian madihin, dengan tujuan dan meningkatkan keterampilan menyimak sekaligus mengenalkan kesenian daerah. Penelitian ini melibatkan 19 anak usia 5-6 tahun di RA Al-Amin Kecamatan Tembilahan-Riau, desain penelitian menggunakan one group pretest posttest. Teknik pengumpulan data menggunakan observasi dan wawancara kemudian dianalisis menggunakan teknik deskriptif kuantitatif. Hasil penelitian menunjukkan bahwa terdapat pengaruh yang signifikan dalam bercerita dengan madihin terhadap keterampilan menyimak anak usia 5-6 tahun yang ditunjukan pada hasil post test lebih besar daripada hasil pre test. Hal ini dapat terlihat ketika anak dapat duduk dengan rapi, antusias, mendengarkan dan memperhatikan cerita dari awal sampai akhir, dapat menyebutkan berbagai tokoh dan sifatnya, serta dapat menceritakan kembali dengan bahasa anak sendiri. Kesenian madihin dapat menarik minat dan perhatian anak, karenanya kesenian ini perlu dikolaborasikan dengan berbagai metode pembelajaran lain agar selanjutnya dapat mengembangkan aspek perkembangan anak seperti kognitif, seni, motorik, dan sosial emosional.
\end{abstract}

Kata kunci: bercerita; madihin; keterampilan menyimak

Copyright (c) 2019 Eva Eriani, Dimyati

$\triangle$ Corresponding author :

Address : Yogyakarta, Indonesia

Email : evaeriani123.2017@student.uny.ac.id

ISSN $\underline{2356-1327}$ (Media Cetak)

ISSN 2549-8959 (MediaOnline) 


\section{INTRODUCTION}

Language development is one of the important aspects regarding to the earlyaged development, since language is a means of communication in order to express knowledge, ideas, thoughts, and feelings towards others. Language development in children is systematically divided into four aspects, starting with listening, speaking, reading, and writing, starting ability for children is concern to the mastery of listening skills, as a basis for mastering the next language aspects (Hurlock, 1978; Jalongo, 2007; Fogelsong, 2016). Listening is the process of brief contemplating and needs high concentration to obtain information and understand the language that is delivered orally (Tarigan, 2008; Hermawan, 2012). Listening skills are commonly applied, since listening is more than what is heard with two ears, but conscious effort thet based on observation and understanding, evaluation and reaction, which requires active mental processes (Oxford, 1993; Chou, 2017; Öztürk, 2018). Listening skills are one of the obligatory requirements which is important, especially in communication, because it needs to be trained early to be well stimulated. In language interaction, children must be able to understand and react to the words of the other person, to enrich the pronunciation of good words and learn various expressions which obtained through listening. Therefore, listening skills have their own urgency to be developed and focused as early as possible as a basis for developing other languages.

Practically, studies revealed that humans use three times of their listening skill more than reading phase activity in average time, yet there is little attention in listening training. In several schools in Detroit, the percentage of reading activities is $52 \%$, while listening is only $8 \%$ ( $\mathrm{Kim} \&$
Phillips, 2014), the assumption that listening will develop in accordance with the development of other languages is considered as a wrong opinion. Language development, especially listening according to Logan \& (Nippold, 2017) consists of 5 stages, such as: hearing, understanding, interpreting, evaluating, and responding. The stages of listening as follows 5-6 years old children or aged 5-6 are still in the second stage, underlined in concern of understanding the language from the perspective of others.

Judging from the pattern of child development, acceleration of language development will occur as a result of symbolic development (Jalongo, 2007), which means that if the development of language symbols has developed, it allows children to learn the language from other people's words. Hence, it can be concluded that the more the children listening and acquiring new vocabularies, sentence patterns, intonation, and so on, the more their language skills are developed. One method for improving listening skills is storytelling (Musfiroh, 2005; Tarigan, 2008). By doing storytelling, it is expected that children will be trained and become creative and critical listeners. Listening skills is a language skill that does not develop by itself. If the process of listening comprehension to a child in bad treatment, the development of other languages is will be indicates the less quality, because children who are trained to listen well will become good and critical listeners.

However, based on the results of observations, when the teacher tells the story, the children still have difficulties in paying attention and not focus, and the children prefer to tell stories with friends, share attention outside the classroom, or try to do other activities. This happens because the implementation of the storytelling method is still not optimal and less of 
variation. Storytelling can be done in many ways, such as using finger puppets, storybooks, pictures, etc (Tadkiroatun, 2009), but the use of media in schools is still not optimal, since teachers tend to tell stories by lecturing methods or using books. the size is not too big. The current study investigates whether there is an effect on the method of telling stories using madihin on children listening skill aged 5-6 years. Based on various problems encountered, in this study the storytelling method was collaborated with madihin.

Madihin grows and develops in Banjarmasin, South Kalimantan, is one of the traditional Banjarese arts that has existed in Tembilahan city, Indragiri Hilir Regency, Riau. The existence of madihin is much influenced by Islamic art such as kasidah and ballads that are often sung by the Banjarese community (Yulianto, 2010). Madihin is a kind of traditional art which in its performance there is a combination of vocal art in the form of ballad songs which contain traditional poetry or rhyme and followed by percussion (a type of Malay drum) which is played by a person who performs madihin, or called pemadihin (Seman, 2002). It is hoped that by implementing storytelling using madihin, it will be more interesting for children to listen to the stories that are presented.

Currently, madihin has been unfamiliar in society, especially children (Rumansyah, 2015) and to maintain the sustainability of madihin as one of the local wisdom, it can be done by socializing the existence and uniqueness of madihin through the world of education, by adopting it as an innovative learning method based on local wisdom at school. Madihin can also be used as a means of moral formation and behavior, which is important to the character education that is proposed by the government.
This research analyzes the listening skills of early children which can be developed optimally by using learning model "story telling using Madihin". Eventhough, the development of listening skills provides new idea to the development of children's language skills, this article presents the learning media which is attractive to the children 5-6 years.

Steps in Madihin (Thaha dan Bachtiar, 2000) consist of:

1. Opening, by hitting as the opening and followed by the sound of a rhyme

2. Set the tabi, which is to bring poems or rhymes to respect the audience, give an introduction, thank you, and apologize if there is a mistake or error in the performance later

3. Delivering the contents (manguran) by conveying poems or poems whose contents are always create a harmony with the theme of performance.

4. Closing, by giving conclusions from what has just been performed.

In this case, the researcher made steps in storytelling using madihin adjusted to the storytelling method and the research subject, the allocation of time to tell is 20 minutes, then the researcher made the following steps:

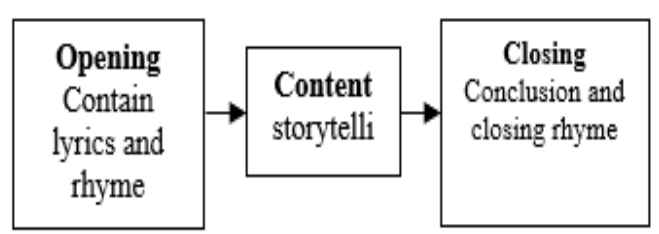

Figure 1. Syntax of storytelling using Madihin

The first step in telling stories using madihin:1) Opening, containing lyrical rhapsody and pantun, this aims to attract attention in condition that the child should be focus on what the teacher will say. 2) Fill in, where the teacher presents the story in simple and mimic language and good intonation, occasionally the teacher hits the 
drum in order to make the story is more interesting, 3) Closing, contains the story conclusions and closing rhymes.

\section{METHODOLOGY}

This study used a quantitative method, which based on empirical and systematic data that can be measured by numbers. The time of the study was conducted in January, located at RA AlAmin Tembilahan, Riau. the subjects in this study were 19 children aged 5-6 years. Indicators and instruments are needed in this study, as a standard used to measure variables. These indicators \& instruments are developed from 4 listening rules according to Liz Spooner \& Jacqui Woodcock (2010) which are combined with Logan \& Loban (Tarigan, 2008) then described as assessment rubrics as a reference in determining the criteria for achieving the development of listening to children.

Table 1. 5-6 years old Children's listening skill table of indicator

\begin{tabular}{|l|l|l|l|l|l|}
\hline \multirow{2}{*}{ Variable } & \multicolumn{1}{|c|}{ Indicator } & \multicolumn{4}{c|}{ Scores } \\
\cline { 2 - 5 } & Sit neatly & $\mathbf{4}$ & $\mathbf{3}$ & $\mathbf{2}$ & $\mathbf{1}$ \\
\hline \multirow{5}{*}{ Listening } & $\begin{array}{l}\text { Looking at the person } \\
\text { who is talking }\end{array}$ & & & & \\
\cline { 2 - 5 } & Calm & & & \\
\cline { 2 - 5 } & Listen carefully & & & & \\
\cline { 2 - 5 } & Enthusiastic & & & \\
\hline & Mention the characters & & & & \\
\cline { 2 - 6 } & $\begin{array}{l}\text { Mention the } \\
\text { characteristics }\end{array}$ & & & \\
\cline { 2 - 6 } & $\begin{array}{l}\text { Retell the story by using } \\
\text { their own language. }\end{array}$ & & & & \\
\hline
\end{tabular}

In order to find out the effect of storytelling using madihin on children's listening skills, researchers used one group pretest-posttest design. Data collection techniques are done by using observations and interviews for several weeks and then analyzed using the T test. Data is collected in the form of relevant documents such as learning implementation plan. In addition, data collection is also done through interviews with teachers and parents about the learning model that is applied until the problems that occur are related to the children's listening skills. Data is also obtained by doing classroom observations, such as the arrangement of classrooms, facilities, and infrastructure in the classroom, and also the learning media that support the stimulation of the child development. The collected data was analyzed using quantitative descriptive techniques with the design of one group pretest-posttest design.

Table 2. Pretest-Posttest Group Design

\begin{tabular}{cccc}
\hline Group & Pretest & $\begin{array}{c}\text { Treatmen } \\
\mathrm{t}\end{array}$ & $\begin{array}{c}\text { Pos } \\
\text { ttes } \\
\mathrm{t}\end{array}$ \\
\hline Experimental & $\mathrm{O} 1$ & $\mathrm{X}$ & $\mathrm{O} 2$ \\
\hline \multicolumn{4}{c}{ Source: Sugiyono, 2011 }
\end{tabular}

\section{RESULTS AND DISCUSSION}

Learning activities in schools start with marching, and do gross motor development, like traditional games, gymnastics, or free play for about 10 minutes. After that the child enters the class, the activity is divided into three activities: opening, main activities, and closing. Storytelling activities are usually given at the beginning or end of learning, their function is the same as stimulating cognitive, language, and even social emotional children. However, the problem is teachers often tell stories without using learning media, as a result the children only pays attention in the beginning or 2-5 minutes. After that the child, will talk to the his or her friends, or begin to move to another seat, there is even a runner in the room.

Storytelling using Madihin begins by arranging the students to be as condusive as possible. Then, the teacher greets the students, and starting humming by beating the mosque drum (opening), and reading the traditional poetry, in order to attract 
students' attention. Second, the teacher started doing storytelling (main activities), in this step, beating the mosque drum and singing. Third, the closing is filled with moral lesson and closing rhyme.

Pre-school children are still at the stage of concrete thinking, storytelling can indeed stimulate children's imagination, but it would be better to tell stories using media so it will be not boring. Sometimes teachers use illustrated storybooks, but because they are small, it makes children become fully initiative in order to be able to look the picture. The story books are available in abound numbers, many dolls are also widely available, but the teacher often tells stories without using any media. The classroom is quite spacious, so it is necessary to position the child close but still comfortable and the sound must be louder so all children can listen. However, a large room also has other effects, such as if the child is tired of listening to the story, the child will run around, or do other games in the classroom.

\section{RESULTS}

The data collected and analyzed were data on the results of listening skills from 19 children who were given treatment which is storytelling using madihin. Beforo the treatment is given, a pre-test was conducted to find out the listening skills of the children, the results are presented in the following table:

Table 2. the result pre test dan post test

\begin{tabular}{lccccc}
\hline Deskripsi & $\begin{array}{c}\mathrm{X} \\
\max \end{array}$ & $\begin{array}{c}\mathrm{X} \\
\min \end{array}$ & $\begin{array}{c}\text { Total } \\
\text { skor }\end{array}$ & $\begin{array}{c}\text { Rata- } \\
\text { rata } \\
\text { skor }\end{array}$ & Presentase \\
\hline Pre test & 21 & 9 & 235 & 12,4 & $51,5 \%$ \\
\hline Post test & 23 & 13 & 346 & 18,2 & $75,8 \%$ \\
\hline
\end{tabular}

The increase in the score results showed that the children listening skill was better than before getting treatment, which can be clearly seen in the following graph:

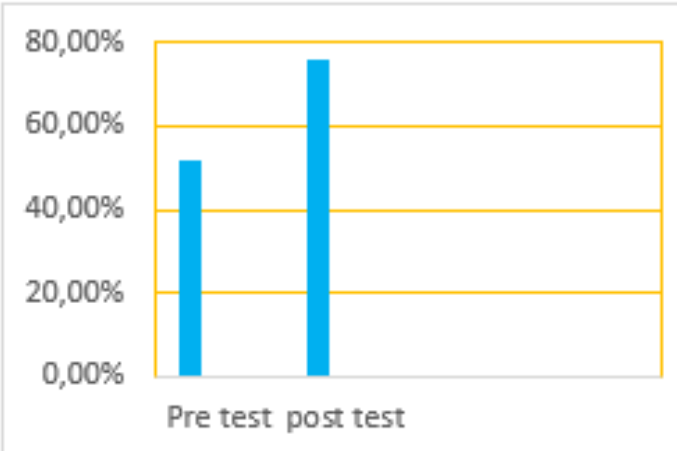

Figure 2. Comparison diagram of the results of the pre test and post test

Based on the diagram above, it can be seen that the percentage of listening skills of children increases after treatment is given, which is storytelling using madihin. The increase from the pre-test to post-test results was $24.3 \%$, with a score difference of $5.85 \%$. This indicates that storytelling using madihin has a positive effect or can improve the aged 5-6 years children's listening skill. In order to find out whether story telling using madihin significantly influences the children ability in listening, then hypothesis testing is done using SPSS 17 for windows with the following results:

Table 3. Hypothesis testing pre test and post

\begin{tabular}{|c|c|c|c|c|}
\hline $\begin{array}{c}\text { Listening } \\
\text { Skills }\end{array}$ & Average & $\mathrm{T}$ & $\mathrm{T}_{\text {table }}$ & Sig \\
\hline Pretest & 12,7 & \multirow{2}{*}{$-18,26$} & \multirow{2}{*}{2,100} & \multirow{2}{*}{0,000} \\
\hline Post test & 18,2 & & & \\
\hline
\end{tabular}

The calculation result shows that $\mathrm{t}$ scores $=-18,26$, the negative sign (-) shows that the pre-test score is lower than the posttest scores. $\mathrm{T} 18,26>\mathrm{T}$ table 2,10, means that there is a significant difference for the significance $5 \%$ and story-telling using madihin gave effects in improving students' listening skills. Therefore, it can be concluded that $\mathrm{H}_{\mathrm{a}}$ is accepted or $\mathrm{H}_{\mathrm{o}}$ is rejected. Hence, it can be concluded that there are significant differences between the results of students's listening skills 
aftter being taught by storytelling using madihin.

\section{DISCUSSION}

Based on the results of the study it was stated that there was an effect of story telling using madihin on children's listening skills. The results showed that story telling using madihin gave effect signifficantly on children's listening skills. The results of the post test listening skills were better than the results of the pre test listening skills. this is because the teacher has never collaborated story telling method with madihin. It turned out that storytelling while singing and followed by a drum and rhymes can attract children's attention. This can be seen when the children can sit neatly, calm down, listen and pay attention to the story from beginning to end, be enthusiastic, can mention various characters and their characteristics, and can retell with their own language.

The results of this study are reinforced by the opinion of Musfiroh (2005) which states that the method of storytelling and singing can cause pleasure, and if the children are happy, the learning process will be more easily acquired. Storytelling using madihin will give children the opportunity to imagine stories that are played, songs and music can also attract interest and give more value to learning (Fadhillah, 2014). By collaborating storytelling using madihin, there are elements of music and singing, to certainly attracts children's attention and improves listening skills.

The storytelling method can improve listening skills, this is seen when children are more active, happy, interested, and enthusiastic about the learning that is carried out, so that children can understand the material provided and the assignments given by the teacher can be completed properly. Research that shows how important listening skills have been done by Donald E. Bird (Lepola et al, 2012) who conducted a study of language skills activities with the following percentage results: humans use $42 \%$ of the time to listen; to speak $25 \%$; to read $15 \%$; and to write $18 \%$. Similar to the study, Paul Ramkin (Tadkiroatun, 2009) showed that $45 \%$ of the time people use to listen, $30 \%$ of the time to talk, $16 \%$ of time to read, and $9 \%$ of time to write. Based on the results of these studies indicate that the percentage of listening skills is the most activity compared to other skills.It can be concluded that in human life the possibility of becoming a listener is greater than being a writer, reader or speaker. This proves that the importance of listening skills for children, because every activity in daily life is related to listening skills. It proves that listening comprehension is important within its purpose dealing various activities such as learning, discussing, conversing, and so on.

The researcher collaborated on the method of telling stories with madihin in listening activities, the results of proving listening skills can be improved through storytelling with students, because learning activities can attract children's interest and attention, giving rise to high learning motivation. This is reinforced by the opinion of Arsyad (2011) which states that the use of learning media can clarify the presentation of messages and information, can increase and direct children's attention so as to create motivation to learn, can overcome space, time and senses and enable direct interaction between teacher and child.

Based on the results of the research presented, the listening skills of each child have increased, which proves that telling stories with madihin can be used as an alternative learning for teachers to stimulate 
the skills of listening to students, especially children aged 5-6 years. Madihin can be used as a means of delivering stories that are fun and easy to understand for children, while introducing one of the local cultures. Along with modernization especially the freedom to watch TV and the use of gadgets make the children unfamiliar with traditional art. If this is allowed, then the various indigenous cultures are only memories. Therefore, the writers collaborate the storytelling method using madihin, in order to improve the children listening skills while preserving one of the regional cultures.

\section{CONCLUSION}

Storytelling using Madihin is the combination of storytelling and preservation of madihin. This method is really attractive with beating drums, rhymes, traditional poetry, and certain rhythms. The contents of stories are suitable to make children listen attentively. Madihin can attract children's interest and attention, so this art needs to be collaborated with other learning methods, in order to develop children's development aspects such as cognitive, artistic, motoric, and social emotional.

\section{ACKNOWLEDGMENT}

Special thanks to the beloved campus Yogyakarta State University and the Postgraduate Program which have been very helpful in supporting the completion of this article. I don't forget to thank my supervisor Pof Suparno, who guided the writer in finishing this article. Finally, the writer would like to thank the family for being the biggest inspiration in everything.

\section{REFERENCE :}

Arsyad, A., Azhar Arsyad, \& Daryanto. (2011). Media Pembelajaran. Jakarta: Raja Grafindo Persada.

Chou, M. H. (2017). A task-based language teaching approach to developing metacognitive strategies for listening comprehension. Journal of Listening, 31 .

https://doi.org/https://doi.org/10.1080/ 10904018.2015.1098542

Fadhillah, M. (2014). Desain Pembelajaran PAUD (A.-R. Media, ed.). Yogyakarta.

Fogelsong, D. F. (2016). Promoting a Pedagogy for Listening Instruction: Primary Grade Teachers Perceptions of Teaching Listening through Interactive Read Alouds. New York: ProQuest.

Hermawan, H. (2012). Keterampilan Berkomunikasi yang Terabaikan. Yogyakarta: Graha Ilmu.

Hurlock, E. B. (1978). Perkembangan Anak. Jakarta: Penerbit Erlangga.

Jalongo, M.R. (2007). Early Childhood Languge Art (4th Ed). New York: Pearson Education Inc.

Jalongo, Mary Renck. (2007). Learning to Listen, Listening to Learn: Building Essential Skills in Young Children. National Association for the Education of Young Children. https://doi.org/ISBN-1-9288-9646-4

Kim, Y.S., \& Phillips, B. (2014). Cognitive Correlates of Listening Comprehension. Reading Research Quarterly, 49(3). https://doi.org/doi:10.1002/rrq.74

Lepola, J., Lynch, J., Laakkonen, E., Silvén, M., \& Niemi, P. (2012). The Role of Inference Making and Other Language Skills in the Development of Narrative Listening Comprehension in 4-6-YearOld Children. Reading Research Quarterly, 47(3), 259-282. 
310 | Integrasi Pengembangan Kreativitas Anak Usia Dini

https://doi.org/10.1002/rrq.020

Selatan.

Nippold MA; Frantz-Kaspar MW; Vigeland

LM. (2017). Spoken Language

Production in Young Adults:

Examining Syntactic Complexity.

American Speech Language Hearing

Yulianto, A. (2010). Madihin: Tradisi

Tutur dari Zaman ke Zaman (Vol. 4).

Banjarmasin: Balai Arkeologi

Banjarmasin Naditira Widya.

Association, 6(5). https://doi.org/ISSN:

1558-9102

Oxford, R. L. (1993). Research update on teaching L2 listening. System, Volume 21(Issue https://doi.org/https://doi.org/10.1016/ 0346-251X(93)90042-F

Öztürk, B. K. (2018). Listening Skills Development in Teaching Turkish as a Foreign Language and The Usage of Metacognitive Strategies. Journal of Education and Training Studies, 6(6). https://doi.org/https://doi.org/10.11114 /jets.v6i6.3108

Rumansyah, A. (2015). Pembelajaran Inquiry Discovery Kesenian Madihin Guna Meningkatkan Kreatifitas Bermusik Siswa di Sekolah. Edusentris, Jurnal Ilmu Pendidikan Dan Pengajaran, 2(2).

Seman, S. (2002). Kesenian tradisional banjar; lamut madihin dan pantun: nanang dan galuh banjar baturai pantun. Banjarmasin: Bina Budaya Banjar.

Spooner, Liz \& Jacqui, W. (2010). Teaching Children To Listen A Practical Approach To Developing Children's Listening Skill's (MPG Books Group, ed.). New York.

Tadkiroatun, M. (2009). Bercerita untuk Anak Usia Dini. Jakarta: Departemen Pendidikan Nasional.

Tarigan, H. . (2008). Menyimak Sebagai Suatu Keterampilan Berbahasa. Bandung: Angkasa Bandung.

Thaha, M. dan Sanderta, B. (n.d.). Pantun, madihin dan lamut. Dinas Pendidikan dan Kebudayaan Tingkat I Kalimantan Selatan: Dewan Kesenian Kalimantan 